\title{
HEALTH LITERACY IN FEMALE - ASSOCIATION WITH SOCIOECONOMIC FACTORS AND EFFECTS ON REPRODUCTIVE HEALTH
}

Milena Maricic ${ }^{1}$, Radmila Amanovic Curuvija², Milos Stepovic ${ }^{3}$

${ }^{1}$ High Health School of Professional Studies in Belgrade, Serbia

${ }^{2}$ Special Hospital for Cerebrovascular Diseases "Sveti Sava" in Belgrade, Serbia

${ }^{3}$ Faculty of Medical Sciences, University of Kragujevac, Serbia

\author{
ZDRAVST VENA PISMENOST ŽENA - UDRUŽENOST \\ SA SOCIOEKONOMSKIM FAKTORIMA I EFEKTI \\ NA REPRODUKTIVNO ZDRAVLJE \\ Milena Maričić ${ }^{1}$, Radmila Amanović Curuvija ${ }^{2}$, Miloš Stepović ${ }^{3}$ \\ ${ }^{1}$ Visoka zdravstvena škola strukovnih studija u Beogradu, Srbija \\ ${ }^{2}$ Specijalna bolnica za cerebrovaskularne bolesti “Sveti Sava” u Beogradu, Srbija \\ ${ }^{3}$ Fakultet medicinskih nauka, Univerzitet u Kragujevcu, Srbija
}

Received / Primljen: 28. 06. 2018.

Accepted / Prihvaćen: 22. 08. 2018.

\begin{abstract}
The aim of the study is to assess the health literacy of women who are using health services within the Gynecology Obstetric Clinic "Narodni Front" in Belgrade. Testing of health literacy was conducted as a cross-sectional study in the period October- November 2012. As instruments of research the following questionnaires are used: Short Test of Functional Health Literacy in Adults and General information questionnaire of respondents who referred to the demographic, social and economic characteristics of respondents, self-assessment of health, use of health services, health knowledge and behavior in the area of reproductive health. Inadequate health literacy level is registered in every ten respondents. The education level of the respondents proved to be a significant predictor of health literacy. Demographic and socio-economic characteristics of the patients (age, occupation, marital status) as well as self-evaluation of the health status were not significantly related to the health literacy. Health literacy respondents did not significantly dependent on risk behaviors related to reproductive health. The level of health literacy is consistent with the knowledge of subjects in the field of protection of reproductive health. Health literacy as the ability to function within the health care system is equally certain by individual characteristics and skills, characteristics of the health and education systems as well as a wide range of social and cultural factors. Health literacy is more systematic than individual problem, so it requires a broader social action.
\end{abstract}

Keywords: health literacy, women, reproductive health

\section{SAŽETAK}

Cilj rada je procena zdravstvene pismenosti žena koje koriste zdravstvene usluge u okviru Ginekološko akušerske klinike "Narodni front" u Beogradu. Ispitivanje zdravstvene pismenosti sprovedeno je kao studija preseka u periodu oktobar-novembar 2012. god. u Ginekolološko-akušerskoj klinici "Narodni front" u Beogradu. Kao instrumenti istraživanja korišćeni su sledeći upitnici: Test za ispitivanje funkcionalne zdravstvene pismenosti kod odraslog stanovništva i upitnik o opštim podacima ispitanica koji se odnosio na demografske, socijalne i ekonomske karakteristike ispitanica, samoprocenu zdravlja, korišćenje $z$ dravstvene službe, zdravstveno stanje $i$ znanje i ponašanje u oblasti reproduktivnog zdravlja. Neadekvatan nivo zdravstvene pismenosti registrovan je kod svake desete ispitanice. Nivo obrazovanja ispitanica se pokazao kao značajan prediktor zdravstvene pismenosti. Demografske i socioekonomske karakteristike ispitanica (životna dob, radni status, bračni status) kao i samoprocena zdravstvenog stanja nisu bili značajno povezani sa zdravstvenom pismenošću. Zdravstvena pismenost ispitanica nije značajno zavisila od rizičnih oblika ponašanja u vezi sa reproduktivnim zdravljem. Nivo zdravstvene pismenosti je u skladu sa znanjem ispitanica iz oblasti očuvanja reproduktivnog zdravlja. Zdravstvena pismenost kao sposobnost funkcioniranja unutar sistema zdravstvene zaštite jednako je određena pojedinim karakteristikama i vještinama, karakteristikama sistema zdravstva i obrazovanja, kao i širokom spektru društvenih $i$ kulturnih faktora. Zdravstvena pismenost je sistematičnija od pojedinačnog problema, pa zahteva širu društvenu akciju

Ključne reči: health literacy, women, reproductive health 


\section{INTRODUCTION}

Health literacy as a form of literacy has become very important for social, economic, and health development (1). The World Health Organization has defined health literacy as "the cognitive and social skills and capacity needed to access, understand and use information in a way that promotes and protects good health" (2). Health literacy enables people to increase control over their health and improve it. Health literacy includes cognitive and social skills which determine the motivation and ability of individuals to obtain, understand and use information in a way that will promote and preserve good health. Health literacy refers to the skills and competencies of people to meet the complex requirements of health in modern society Division into basic functional, interactive and critical health literacy shows that in the health system patients are required to have at least a satisfactory level of functional health literacy in order to participate in the realization of their own health care (3-5). Health literacy as the ability to function within the health care system is equally certain by individual characteristics and skills, characteristics of the health and education systems as well as a wide range of social and cultural factors. Numerous studies have shown that low levels of health literacy causes more frequent use of emergency combat, often needs for hospital treatment, frequent drug use, less use of preventive services, which contributes to higher costs for the health system $(6,7)$. Previous studies have shown a positive effect of education and literacy on the health of the population. Previous studies have shown a positive effect of education and literacy on the health of the population. Reports from "State of the World's Mother" by the organization Save the Children (8) estimated the rate of literacy of the adult women, as one of ten key indicators to determine the "well-being of women." Literature data also suggest an association between health literacy and prevention behaviors among women $(9,10)$. The World Health Organization has defined women's health literacy as a "cognitive and social skills which determine the motivation and ability of women to access, understand and use information in ways which promote and preserve their health and the health of their children." $(11,12)$

The aim of the study is to assess the health literacy of women who are using health services within the Gynecology Obstetric Clinic "Narodni Front" in Belgrade.

\section{METHOD}

Testing of health literacy was conducted as a crosssectional study in the period October- November 2012. in Gynecology Obstetric Clinic "Narodni front" in Belgrade.

As instruments of research the following questionnaires are used:

- An abbreviated version of the questionnaire TOFHLA (STOFHLA population - Short Test of Functional Health Literacy in Adults)) - test of functional health literacy among the adult. TOFHLA original version of the questionnaire is available in two forms (standard and abbreviated - STOFHLA) (13).

- General information questionnaire of respondents who referred to the demographic, social and economic characteristics of respondents, self-assessment of health, use of health services, health knowledge and behavior in the area of reproductive health.

The subjects of research were the beneficiary of tertiary health care of Gynecology and Obstetrics Clinic "Narodni front" in Belgrade. The criteria for entering the respondents in the survey were:

- The age group (over 18 years)

- The willingness to voluntarily participate in the study

- Literate person

- Possession of visual skills to complete the questionnaire

- A medical condition that allows them to be able to complete the questionnaire.

Before the start of the research respondents were familiar with the objectives and procedures of research.

An abbreviated version of the questionnaire TOFHLA (STOFHLA) consists of 36 parts which assesses the ability to read and understand information from health care environment.

Scoring is done as like in the standard version of TOFHLA questionnaire in the section pertaining to the understanding of reading, so that the total number of points obtained by a shortened version of the questionnaire was 36. TOFHLA has already adapted to the Serbian language and showed good internal consistency (Cronbach's alpha = 0.94). Evaluation was as following:

- Inadequate health literacy implied between 0 and 16;

- The marginal was between 17 and 22 and

- Adequate health literacy between 23 and 36 points.

In standard and shortened version of the questionnaire, the categories of health literacy included the following:

- Inadequate health literacy implied the impossibility of reading and understanding the text related to health;

- Marginal health literacy refers to the difficulty in reading and understanding the text referred to health and

- Adequate health literacy is the ability to read and understand most of the texts related to health $(13,14)$.

The obtained results were analyzed using the methods of descriptive and inferential statistics. For statistical analysis, we used the software package program Statistical Package for the Social Sciences, SPSS 17.0. Following descriptive statistics were used: measures of central tendency (mean and median), the measures of variability (standard deviation) for continuous variables and the absolute frequencies and percentages for categorical variables. For testing the significance of differences we were using chi square test (contingency tables). We tested the differences in health literacy in relation to demographic, social and economic characteris- 
tics, the self-assessment of health, use of health services, risk behavior and knowledge in the field of protection of reproductive health. In all cases of differential testing, the statistical test is accepted if the probability of the null hypothesis was equal to or less than $5 \%$.

\section{RESULTS}

The results showed that from the complete number of subjects, 121 (90.3\%) had adequate level of health literacy, while the $8(6 \%)$ had a marginal, and the inadequate level of health literacy show up in $5(3.7 \%)$ of the respondents. The largest number (95.1\%) of respondents with adequate health literacy is in the category aged 18 to 29 years, while one fifth of inadequate is from category 40 to 49 years.

In relation to the marital status of respondents, it is noted that most of them (96.4\%) with adequately literacy are single subjects, and at the highest $(12.6 \%)$ with inadequately literacy are married $\left(x^{2}=2.488 ; p=0.288\right)$. A statistically significant difference in the level of health literacy has been observed in relation to the level of education of the patients $\left(x^{2}=8.627 ; p=0.013\right)$. Most of them $(94.5 \%)$ with adequate health literacy were with a college education, and half (50.0\%) with inadequately literacy were in an incomplete or primary school. It can be seen that the $5.5 \%$ inadequately literacy were the patients with a college education, and every tenth was with finished high school.

Unemployed women were with an adequate level of health literacy as like the $90.2 \%$ of women from the category of employed. Nearly one-fifth of inadequately is from group of the housewife, students / high school student, unable to work and retired $\left(x^{2}=3.595 ; p=0.166\right)$. No statistically significant difference was observed in the level of health literacy in relation to the self-assessment of financial situation. The largest number of adequate health literate women was in category that assessed their financial situation as well.

An adequate level of health literacy had the highest number (93\%) of women who assess their health as good, while $15.4 \%$ of women with inadequate health literacy assessed its health as average. Also, an adequate level of health literacy was recorded in $87.5 \%$ of respondents who perceived their health as poor $\left(\chi^{2}=2.223 ; \mathrm{p}=0.329\right)$.

It was not observed association between examined factors of risk behavior and health literacy. The largest number $(96.9 \%)$ of patients with an adequate level of health literacy use contraception, while $12.8 \%$ with inadequate literacy don't use any form of protection from sexual transmitted diseases and unwanted pregnancy. An adequate level of health literacy was observed in $91.7 \%$ of the respondents which use preservative as a mechanical contraceptive. Almost in every tenth respondent who do not use condoms reveals inadequate levels of health literacy. In $90.4 \%$ of respondents who correctly answered the question, to what purpose is performed Pap test, there was an adequate level of health literacy. However, almost one in ten patients with inadequate levels of health literacy knew that the Pap test is performed to detect premalignant and malignant changes in the cervix. It can be noticed that in the category of patients with inadequate health literacy, the greater number was from those who gave the correct answer than from those who gave incorrect answers to the question $\left(x^{2}=0.575 ; p=0.490\right)$, table 1 .

\section{DISCUSSION}

Studies worldwide show that health literacy is the strongest predictor of health status of an individual, even before the age, education, income, employment or ethnicity (15). A higher level of health literacy is significantly associated with higher social status, a higher frequency of monitoring health emissions but it is also associated with a younger age. It turned out that health literacy is also linked to health status, health behavior, availability and use of health care services (16).

A lot of factors have been identified as factors related to different levels of health literacy. Studies are showing correlation between level of health literacy and social determinants, so that the groups with proportionally higher risk limited literacy are defined. Research conducted in eight countries of the European Union has registered an inadequate general health literacy by $12 \%$ of respondents, and more than one third of respondents had a problematic level of health literacy, so that almost every second respondent had limited health literacy. The results of this study varied between countries. The highest degree of health literacy was recorded in the Netherlands, where the $72 \%$ of subjects were registered with excellent and satisfactory level of health literacy, and a high level of health literacy is recorded in Ireland, too (61.3\%). In both countries, less than $10 \%$ of respondents registered an inadequate level of health literacy (17).

Many studies have shown that a large percentage of the adult population (53\%) have health literacy at the secondary level, $22 \%$ at primary level and $14 \%$ below the basic level of health literacy, which leads to conclusion that they don't have the ability to accept, understand and use useful information for their health (18). Research conducted in Canada showed that $60 \%$ of adult Canadians (aged 16) has a problem to accept and understand health information and to have difficulty in making the correct medical decisions (19). The low level of health literacy was recorded in research in Australia, where 59\% of respondents had low or very low levels of health literacy (20).

Studies of health literacy in South America show that more than one-third (32.4\%) healthy individuals who have used the services of the University Hospital and other hospitals in Sao Paulo (Brazil) had inadequate or marginal health literacy level (21) 19 and $30,1 \%$ of inadequate health literacy in Argentina by research (22). Research results in a health insurance literacy Ireland showed that $19.9 \%$ of them had a high probability limited functional 
Tabel 1. Health literarcy relative to demographic and socioeconomic caracteristics

\begin{tabular}{|c|c|c|c|}
\hline Characteristics of female subjects & Adequate health literacy N (\%) & Inadequate health literacy $\mathbf{N}(\%)$ & p value \\
\hline \multicolumn{4}{|l|}{ Age of life } \\
\hline $18-29$ years & $39(95.1)$ & $2(4.9)$ & \multirow{4}{*}{0.201} \\
\hline 30-39 years & $55(91.7)$ & $5(8.3)$ & \\
\hline $40-49$ years & $19(79.2)$ & $5(20.8)$ & \\
\hline 50 and more years & $8(88.9)$ & $1(11.1)$ & \\
\hline \multicolumn{4}{|l|}{ Marital status } \\
\hline married & $76(87.4)$ & $11(12.6)$ & \multirow{3}{*}{0.288} \\
\hline unmarried & $27(96.4)$ & $1(3.6)$ & \\
\hline other & $18(94.7)$ & $1(5.3)$ & \\
\hline \multicolumn{4}{|l|}{ Education } \\
\hline faculty & $52(94.5)$ & $3(5.5)$ & \multirow{3}{*}{0.013} \\
\hline high/higher or middle school & $67(89.3)$ & $8(10.7)$ & \\
\hline uncompleted or elementary school & $2(50)$ & $2(50.0)$ & \\
\hline \multicolumn{4}{|l|}{ Employment } \\
\hline employed & $83(90.2)$ & $9(9.8)$ & \multirow{3}{*}{0.166} \\
\hline unemployed & $19(100)$ & $0(0.0)$ & \\
\hline other & $19(82.6)$ & $4(17.4)$ & \\
\hline \multicolumn{4}{|l|}{ Financial situation } \\
\hline good & $42(97.7)$ & $1(2.3)$ & \multirow{3}{*}{0.138} \\
\hline average & $67(87.0)$ & $10(13.0)$ & \\
\hline bad & $12(85.7)$ & $2(14.3)$ & \\
\hline \multicolumn{4}{|l|}{ Self-assessment of health } \\
\hline good & $80(93.0)$ & $6(7.0)$ & \multirow{3}{*}{0.329} \\
\hline average & $33(84.6)$ & $6(15.4)$ & \\
\hline bad & $7(87.5)$ & $1(12.5)$ & \\
\hline \multicolumn{4}{|l|}{ Use of contraception } \\
\hline yes & $31(96.9)$ & $1(3.1)$ & \multirow{2}{*}{0.334} \\
\hline no & $90(87.15)$ & $12(12.85)$ & \\
\hline \multicolumn{4}{|l|}{ Use of condoms } \\
\hline yes & $44(91.7)$ & $4(8.3)$ & \multirow{2}{*}{0.91} \\
\hline no & $76(89.3)$ & $9(10.7)$ & \\
\hline \multicolumn{4}{|l|}{ Purpose of using Papa test } \\
\hline correct & $103(90.4)$ & $11(9.6)$ & \multirow{2}{*}{0.575} \\
\hline incorrect & $17(94.4)$ & $1(5.6)$ & \\
\hline
\end{tabular}

- relative to chi square test

health literacy, $22.5 \%$ of contained functional literacy and $57.6 \%$ of an adequate level of health literacy (23). The study of health literacy in Israel showed that $29.4 \%$ of respondents have inadequate literacy, $12.6 \%$ and $58.0 \%$ marginal adequate level of health literacy (24).

Some research has identified sex as an important factor of health literacy, but there are also studies in which this relationship is not clearly established (25-27). No statistically significant difference was found in the level of health literacy between married, unmarried, and others, so that the marital status of respondents could not be identified as a factor that has an impact on the level of health literacy. Although age was not significantly associated with the level of health literacy, it can be seen that the largest num- ber of respondents had proper literacy in the category up to 39 years while almost half of respondents older than 40 years had an inadequate level of health literacy. The results of European studies have shown a negative correlation between health literacy and age, except in the Netherlands (17). The results of research in the US shows that respondents aged 65 years and older have a lower average health literacy in relation to adult literacy at a young age. Adults aged 25 to 39 years had a higher average health literacy compared to other age groups. The part of adults with average health literacy, except in the group 65 years and over, ranged from $53 \%$ to $58 \%$, and among adults aged 65 years and over $38 \%$ (18). The results of studies of health literacy in South Australia also showed that the propor- 
tion of people with inadequate health literacy levels, older than 65 years was higher than $50 \%$, while the number of inadequate literacy among the younger respondents were less (11\%). In addition to age, the level of education proved to be a significant predictor of health literacy in the available literature. The level of health literacy in a number of studies, irrespective of the population and the health care environment, dependent on the level of education, namely people with higher education levels showed significantly better results in health literacy (20). The results of research in the US shows that health literacy is directly dependent on the level of education. More than three-quarters of the adult population with a level of education with not completed high school had basic or below basic health literacy levels, and the percentage is significantly decreased as the level of education that is growing namely level of health literacy has been growing with the level of education (18). The results of our study do not differ with the available literature considering that the statistically significant difference level of health literacy in relation to the education level of respondents is shown.

Employment status of respondents, according to research, is also important for the health literacy. However, the results of our study showed that all the respondents who are not employed, had an adequate level of health literacy, while one in five respondents in category (housewife, student of / student, unable to work and retired) had inadequate levels of health literacy. Data from previous studies shows that the poor financial situation is contributing factor in lower levels of health literacy $(17,25)$. The results of our study showed that there is a significant difference in the level of health literacy among respondents who assess their financial situation as good, average or bad.

A study conducted in Iran was aimed to assess health literacy of women on the subject - cervical cancer in reproductive age and related factors. Almost half (47.2\%) of participants had limited health literacy, and health literacy was associated with education, employment, income, search for counseling. Low level of education, unemployed woman and lower income had a significantly and less counseling affected on the reproductive health of woman. There was no relationship between health literacy and age. Adapting health education interventions in relation to the different levels of the health literacy of women may increase the frequency of use of screening examinations for cervical (28).

Evaluation and research on health literacy of women in Taiwan and its links with health behavior has shown that an adequate level of health literacy is often associated with positive health behavior, but it is not so when it comes to women smokers (29).

The health status of the respondents, namely self-assessment of health proved to be a factor that was not significantly associated with the level of health literacy. Data from other studies suggest a link between health literacy and self-assessment in health namely self-assessment of the health conditions are often associated with the func- tional capacity, morbidity and is an important determinant of the state of health $(25,26)$.

\section{CONCLUSION}

The right to health literacy should exist as there is a universal right to health care. Although health literacy is the product of individual capacity, it is also conditioned by the complexities of the health care system. Therefore, it is necessary to create political awareness of health literacy, with the aim of shared responsibility witch should include politicians, professionals and whole society. Health literacy should be understood as a key determinant of health and effective strategies and actions for improvement should be created.

\section{REFERENCES}

1. Kickbusch I. The Health Society: importance of the new policy proposal by the EU Commission on Health and Consumer Affairs. Health Promotion International 2005; 20(2): 101-103.

2. Catford, J. The Bangkok Conference: steering countries to build national capacity for health promotion (Editorials). Health Promotion International 2005; 20(1) :1-6

3. Sørensen K, Broucke SV, Fullam J, Doyle G, Pelikan J, Slonska Z, Brand H . Health literacy and public health: A systematic review and integration of definitions and models. BMC Public Health. 2012; 12:80.

4. Baker DW, Gazmararian JA, Sudano J, Patterson M. The association between age and health literacy among elderly persons. J Gerontology 2000; 55(6): 368-374.

5. Kickbusch I. Health literacy: a search for new categories. Health Promotion International 2002; 15(3): 183-4

6. Brown DR, Ludwig R, Buck GA, Durham D, Shumard T, Graham SS. Health literacy: universal precautions needed. Journal of Allied Health, 2003; 33: 150-5

7. Kickbusch I. The Health Society: importance of the new policy proposal by the EU Commission on Health and Consumer Affairs. Health Promotion International 2005; 20(2): 101-103.

8. Sanders LM, Shaw JS, Guez G, Baur C, Rudd R. Health literacy and child health promotion: implications for research, clinical care, and public policy. Pediatrics 2009; 124(3): 306-14.

9. Pagán JA, Brown CJ, Asch DA, Armstrong K, Bastida E, Guerra C. Health Literacy and Breast Cancer Screening among Mexican American Women in South Texas. J Cancer Educ. 2012;27(1): 132-7

10. Hasnain-Wynia R, Wolf MS. Promoting health care equity: is health literacy a missing link? Health Serv Res 2010;45: 897-903.

11. Desjardins R. Determinants of literacy proficiency: a lifelong-lifewide learning perspective. IJSR. 2003;39(3): 205-245. 
12. Bertakis KD, Azari R. Patient-Centered Care: The Influence of Patient and Resident Physician Gender and Gender Concordance in Primary Care. J Womens Health. 2012;21(3): 326-333.

13. Wills J. Health literacy: new packaging for health education or radical movement? International Journal of Public Health. 2009;54(1):3-4

14. Jovic-Vranes A, Bjegovic-Mikanovic V, Marinkovic J. Functional health literacy among primary health-care patients: data from the Belgrade pilot study. Journal of Public Health 2009; 31(4):490-495

15. Aguirre AC, Ebrahim N, Shea JA. Performance of the English and Spanish S-TOFHLA among publicly insured Medicaid and Medicare patients. Patient Educ Counsel. 2005;56: 332-339

16. Duong VT, Lin IF, Sorensen K, Pelikan JM, Van Den Broucke S, Lin YC, Chang PW. Health Literacy in Taiwan: A Population-Based Study. Asia Pac J Public Health. 2015;27(8): 871-80.

17. Rowlands G, Shaw A, Jaswal S, Smith S, Harpham T. Health literacy and the social determinants of health: a qualitative model from adult learners Health Promotion International, 2017;32:130-138

18. Sørensen K, Van den Broucke S, Fullam J et al. Health literacy and public health: a systematic review and integration of definitions and models. BMC Public Health, 2012. 12:80.

19. Cheong SM, Mohamad Nor NS, Ahmad MH et al. Improvement of health literacy and intervention measurements among low socio-economic status women: findings from the MyBFF@home study. BMC Womens Health. 2018;18(1): 99.

20. Protheroe J, Whittle R, Bartlam B et al. Health literacy, associated lifestyle and demographic factors in adult population of an English city: a cross-sectional survey. Health Expect. 2017;20(1): 112-119.

21. Carthery-Goulart MT, Anghinah R, Areza-Fegyveres $\mathrm{R}$, et al. Performance of a Brazilian population on the test of functional health literacy in adults. Rev Saude Publica. 2009;43(4): 631-8.

22. Konfino J, Mejía R, Majdalani MP, Pérez-Stable EJ. Health literacy in patients attending a University Hospital. Medicina (B Aires). 2009;69(6): 631-4.

23. Sørensen K, Pelikan JM, Röthlin F et al. Health literacy in Europe: comparative results of the European health literacy survey (HLS-EU). Eur J Public Health. 2015;25(6): 1053-1058.

24. Baron-Epel O, Balin L, Daniely Z, Eidelman S. Validation of a Hebrew health literacy test. Pat educ and Counsl 2007;67:235-239.

25. Ziegler J. How literacy drives up health costs. Business and Health 1998;16: 53-54.

26. Adams RJ, Appleton SL, Hill CL, Dodd M, Findlay C, Wilson DH. Risks associated with low functional health literacy in an Australian population. Med J Aust. 2009;191(10): 530-4

27. Wagner VC, Knight K, Steptoe A, Wardle J. Functional health literacy and health-promoting behaviour in a national sample of British adults. J Epidemiol Community Health 2007;61: 1086-1090.

28. Bazaz M, Shahry P, Latifi SM, Araban M. Cervical Cancer Literacy in Women of Reproductive Age and Its Related Factors. J Cancer Educ. 2017; doi: 10.1007/ s13187-017-1270-z.

29. Lee SY1, Tsai TI, Tsai YW, Kuo KN. Health Literacy and Women's Health-Related Behaviors in Taiwan. Health Educ Behav. 2012;39(2): 210-8. 